\title{
The Effects of Long Term High Environmental Temperature on Cellular Enzyme Activities from Different Organs ${ }^{1}$ )
}

\author{
Eitan Bogin ${ }^{1}$, Huo Cheng Peh ${ }^{2}$, Yaakov Avidar ${ }^{1}$, Bat Ami Israeli ${ }^{1}$ and Avigdor Kahaner ${ }^{3}$ \\ 1 Kimron Veterinary Institute, Tel Aviv University School of Medicine, Beit Dagan, Israel \\ 2 National Chung Hsing University, Taichung, Taiwan, Republic of China \\ 3 Faculty of Agriculture, Hebrew University, Rehovot, Israel
}

Summary: The effect of long term hyperthermia on enzyme levels in the chicken heart and breast muscles, brain, kidney, liver and lung were studied. Three weeks old chickens were exposed to environmental temperature of $24^{\circ} \mathrm{C}$ (control group) and $32{ }^{\circ} \mathrm{C}$ (experimental) for a duration of 5 weeks, after which the birds were sacrificed, organs removed, homogenized and centrifuged at $22000 \mathrm{~g}$ for 30 minutes. Enzyme activities in the supernatant were measured. The following enzymes were analysed: alanine and aspartate aminotransferase, alkaline phosphatase, creatine kinase, lactic dehydrogenase and $\gamma$-glutamyltransferase.

Significant changes in cellular enzyme activities were seen in the organs studied. Based on the percentage of changes compared to the controls, large and significant changes were seen in the creatine kinase from heart muscle (mean increase of $328 \%$ ), aspartate aminotransferase from the brain (mean increase of $148 \%$ ) and $\gamma$-glutamyltransferase from the kidney (mean increase of $105 \%$ ). The organs showing the smalles changes were breast muscle and liver.

\section{Introduction}

Disturbance of the heart regulating mechanism of the body may result from high environmental temperature, high humidity and inadequate ventilation. Ambient temperatures exceeding the thermoneutral zone lead to elevated core temperature and consequently initiate a number of responses leading to the neutralization of the metabolic changes on one hand and reduction of body temperature on the other hand (1-4). Chronic and acute heat exposure are among the stress factors affecting the metabolism and causing injury to the vascular endothelium and consequently, altered vascular permeability and oedema. Furthermore, above a certain thermal limit, denaturation of proteins takes place, affecting metabolism and membrane characteristics $(5,6)$. Hyperthermia is manifested by metabolic changes, disturbed electrolyte balance, vascular dilatation, hyperpnea, rapid pulse, weakness, muscle tremors and collapse $(7-13)$.

In the hen, which lacks sweat glands, one adaptational response to cool the body is panting. This in turn leads to polypnea and higher gas exchange rate resulting in loss of carbon dioxide and enrichment of oxygen in the blood, worsening blood gas balance with the development of respiratory alkalosis $(1,8,14)$.

Studying the response of chickens to heat stress revealed large variations in their response to heat as evaluated by

1) The research was sponsored by GIARA - German-Israeli Agricultural Research Association. blood composition and behaviour. Changes occurred in many of the blood constituents following heat stress. They included glucose, uric acid, calcium, inorganic phosphorus, thyroxin, and electrolytes (15). There were differences in some of the blood constituents between surviving and non-surviving birds, suggesting a possible mechanism associated with survivability to heat stress (16).

While animals adapt to changes in carbon dioxide and oxygen concentrations by regulating phosphorylated intermediates such as 2,3-bisphosphoglycerate, inositol-5phosphate, etc, it was shown that the type of haemoglobin also changes following heat stress associated with respiratory alkalosis (17-19).

The objective of the present study was to evaluate the intracellular biochemical changes caused by prolonged hyperthemia and the possible biological mechanisms taking place during adaptation to high ambient temperatures.

\section{Materials and Methods}

Animals

At 3 weeks of age, medium-heavy Rhode Island Red broiler chicks were assigned to individual cages $(35 \times 45 \mathrm{~cm})$ in a climate controlled chamber with constant temperature set at $32{ }^{\circ} \mathrm{C}$ and relative humidity of $40-50 \%$ (heat stressed) and the other groups (control group) in another constant temperature chamber set at $24^{\circ} \mathrm{C}$ and relative humidity of $40-50 \%$. All management practices were the same, with a standard at-libitum feeding of a commercial feed. Continuous light and unlimited water were provided throught the 
experimental period. The birds were kept under these conditions for about 5 wceks, when they reached a body weight of around $2000 \mathrm{~g}$.

\section{Tissue analysis}

Immediately following sacrifice of the broilers, tissue samples were taken, put on ice and taken to the laboratory for analysis. Tissues analysed were heart and breast muscle, brain, kidney, liver and lung. The heart, brain and kidney were removed completely, while from the liver, breast muscle and lungs only 10 grams were taken for analysis.

The tissues were rinsed with cold saline, iveighed, and cut into small pieces which were then rewashed to remove excess blood and tissue debris. Tissue cut weighing between $1-2 \mathrm{~g}$ were taken and homogenized in 10 volumes of cold Tris- $\mathrm{HCl}$ buffer $(0.01$ $\mathrm{mol} / \mathrm{l}, \mathrm{pH}$ 7.2) with a glass-teflon homogenizer. The homogenate was centrifuged at $22000 \mathrm{~g}$ for 30 minutes and the supernatant obtained was used for enzyme analysis (20). Enzymes were analyzed within 24 hours after sacrifice.

\section{Enzymes}

Alkaline phosphatase (phosphor monoester phosphohydrolase (alkaline optimum) EC 3.1.3.1) was determined colorimetrically (21).

Alanine aminotransferase ( $L$-alanine : 2 -oxoglutarate aminotransferase; EC 2.6.1.2) and aspartate aminotransferase ( $L$-aspartate : 2 oxoglutarate aminotransferase; EC 2.6.1.1) were determined enzymatically $(22,23)$.

Creatine phosphokinase (ATP : creatine-N-phosphotransferase, EC 2.7.3.2) was medsured enzymatically (24).

Lactic dehydrogenase (lactate : $\mathrm{NAD}^{+}$oxidoreductase, EC 1.1.1.27) was measured spectrophotometrically (25).

$\gamma$-Glutamyltransferase (EC 2.3.2.2) was measured spectrophotometrically (26).

Protein concentration in the supernatant was determined using the Lowry method (27) and activity was expressed in international units per gram protein.
Enzyme activities werc determined using the "Kone Specific" autoanalyzcr. Both internal and external quality assurance programs were used.

\section{Statistics}

Means, standard deviations and degree of significance of the variability between the groups were done using the SAS program (28).

\section{Results}

The effects of long term hyperthermia on organ enzyme activities are shown in table 1 . In the brain, except for lactic dehydrogenase, enzymes studies showed higher activities, ranging from $21-148 \%$, with lactic dehydrogenase showing a lower activity (mean $46 \%$ ) in the hyperthermic birds in comparison to the controls.

In breast muscle, a mixed pattern of changes was seen, with alkaline phosphatase, aspartate aminotransferase, and lactic dehydrogenase decreasing and alanine aminotransferase and creatine kinase increasing in the hyperthermic chickens in comparison to the controls.

In heart muscle from hyperthermic chickens except for alkaline phosphatase which showed a small reduction of activity (mean of $16 \%$ ), all measured enzyme activities showed large increases (means from $40-328 \%$ ), led by creatine kinase which increased by $328 \%$ in comparison to the controls. A relatively large increase (mean of $189 \%$ ) was also seen with aspartate aminotransferase.

A uniform pattern was seen in the kidney, where all enzymes studies showed increased activites $(11-105 \%)$, led by $\gamma$-glutamyltransferase.

Tab. 1 Effect of environmental temperature and long term hyperthermia on organ enzyme level (mean \pm standard deviation; $n=16$ )

\begin{tabular}{|c|c|c|c|c|c|c|c|}
\hline \multirow{2}{*}{$\begin{array}{l}\text { Enzyme } \\
\text { (U/g protein) }\end{array}$} & \multirow{2}{*}{$\begin{array}{l}\text { Temper- } \\
\text { ature } \\
\left({ }^{\circ} \mathrm{C}\right)\end{array}$} & \multicolumn{6}{|l|}{ Organ } \\
\hline & & Brain & Breast muscle & Heart muscle & Kidney & Liver & Lung \\
\hline $\begin{array}{l}\text { Alkaline } \\
\text { phosphatase }\end{array}$ & $\begin{array}{l}24 \\
32 \\
\Delta \% ; \mathrm{P}\end{array}$ & $\begin{array}{l}42.5 \pm 23.5 \\
51.5 \pm 15.4 \\
+21\end{array}$ & $\begin{array}{l}15.7 \pm 6.5 \\
6.9 \pm 2.7 \\
-56\end{array}$ & $\begin{array}{l}45.1 \pm 12.3 \\
37.9 \pm 8.7 \\
-16\end{array}$ & $\begin{array}{l}67.7 \pm 34.6 \\
124.4 \pm 32.2 \\
+84 ; *\end{array}$ & $\begin{array}{l}37.7 \pm 17.8 \\
49.2 \pm 14.9 \\
+31\end{array}$ & $\begin{array}{l}39.2 \pm 19.5 \\
56.3 \pm 20.2 \\
+44\end{array}$ \\
\hline $\begin{array}{l}\text { Alanine } \\
\text { aminotransferase }\end{array}$ & $\begin{array}{l}24 \\
32 \\
\Delta \% ; \mathrm{P}\end{array}$ & $\begin{array}{l}14.8 \pm 7.0 \\
24.4 \pm 2.4 \\
+65 ;\end{array}$ & $\begin{array}{l}9.3 \pm 2.1 \\
10.2 \pm 3.1 \\
+10\end{array}$ & $\begin{array}{l}23.3 \pm 15.4 \\
67.4 \pm 19.7 \\
+189 ; *\end{array}$ & $\begin{array}{l}17.5 \pm 8.6 \\
25.9 \pm 10.8 \\
+48\end{array}$ & $\begin{array}{l}10.1 \pm 5.2 \\
11.7 \pm 2.8 \\
+16\end{array}$ & $\begin{array}{l}1.2 \pm 0.5 \\
1.9 \pm 0.8 \\
+58\end{array}$ \\
\hline $\begin{array}{l}\text { Aspartate } \\
\text { aminotransferase }\end{array}$ & $\begin{array}{l}24 \\
32 \\
\Delta \% ; \mathrm{P}\end{array}$ & $\begin{array}{l}770 \pm 206 \\
1911 \pm 454 \\
+148 ; *\end{array}$ & $\begin{array}{l}674 \pm 164 \\
421 \pm 38 \\
-38 ; *\end{array}$ & $\begin{array}{l}2740 \pm 459 \\
3844 \pm 651 \\
+40\end{array}$ & $\begin{array}{l}604 \pm 132 \\
1011 \pm 145 \\
+67 ; *\end{array}$ & $\begin{array}{l}482 \pm 134 \\
760 \pm 210 \\
+58\end{array}$ & $\begin{array}{l}76 \pm 22 \\
147 \pm 30 \\
+95 ; *\end{array}$ \\
\hline $\begin{array}{l}\text { Creatine } \\
\text { phosphokinase }\end{array}$ & $\begin{array}{l}24 \\
32 \\
\Delta \% ; \mathrm{P}\end{array}$ & $\begin{array}{l}7071 \pm 2013 \\
10515 \pm 685 \\
+49 ; *\end{array}$ & $\begin{array}{l}37,533 \pm 9142 \\
59,545 \pm 10240 \\
+59 ; *\end{array}$ & $\begin{array}{l}3497 \pm 1167 \\
14,977 \pm 5204 \\
+328 ; *\end{array}$ & $\begin{array}{l}500 \pm 201 \\
944 \pm 442 \\
+89\end{array}$ & $\begin{array}{l}43.4 \pm 21.6 \\
63.2 \pm 23.0 \\
+46\end{array}$ & $\begin{array}{l}423 \pm 119 \\
298 \pm 76 \\
-30\end{array}$ \\
\hline $\begin{array}{l}\text { Lactic } \\
\text { dehydrogenase }\end{array}$ & $\begin{array}{l}24 \\
32 \\
\Delta \% ; \mathrm{P}\end{array}$ & $\begin{array}{l}3767 \pm 787 \\
2056 \pm 222 \\
-46 ; *\end{array}$ & $\begin{array}{l}47,162 \pm 11677 \\
41,368 \pm 3955 \\
-12\end{array}$ & $\begin{array}{l}8199 \pm 1798 \\
12835 \pm 2558 \\
+57 ; *\end{array}$ & $\begin{array}{l}3680 \pm 725 \\
4083 \pm 660 \\
+11\end{array}$ & $\begin{array}{l}2926 \pm 922 \\
2905 \pm 652 \\
-1\end{array}$ & $\begin{array}{l}794 \pm 226 \\
630 \pm 210 \\
-21\end{array}$ \\
\hline $\begin{array}{l}\gamma \text {-Glutamyl- } \\
\text { transferase }\end{array}$ & $\begin{array}{l}24 \\
32 \\
\Delta \% ; \mathrm{P}\end{array}$ & $\begin{array}{l}- \\
- \\
-\end{array}$ & $\begin{array}{l}- \\
-\end{array}$ & $\begin{array}{l}- \\
- \\
-\end{array}$ & $\begin{array}{l}19.8 \pm 9.3 \\
40.5 \pm 6.1 \\
+105 ; *\end{array}$ & $\begin{array}{l}- \\
- \\
-\end{array}$ & $\begin{array}{l}- \\
-\end{array}$ \\
\hline
\end{tabular}

* significantly different at $\mathrm{P}<0.05$ 
In the liver from hyperthermic chicken, the changes in enzyme activities ranged from none to a mean increase of $58 \%$ in aspartate aminotransferase in comparison to the controls.

Changes in enzyme activities from hyperthermic lungs ranged in decreases in lactic dehydrogenase (mean of $21 \%$ ) and creatine kinase (mean of $30 \%$ ) to increases ranging from means of $44-95 \%$ in the activities of alkaline phosphatase, alanine and aspartate aminotransferases, in comparison to the controls (tab. 1).

The ratios of the enzymes lactic dehydrogenase to creatine kinase, and lactic dehydrogenase to aspartate aminotransferase, in tissues from chicken kept at regular higher environmental temperatures are shown in table 2.

As seen, differences in the enzyme ratios resulted from prolonged hyperthermia, indicating changes in the metabolism caused during the adaptation to hyperthermia. The degrees of metabolic changes are reflected from the degree of the ratio changes. The lowest lactic dehydrogenase to creatine kinase ratio was seen in the brain (0.53) from normothermic chickens which further decreased to 0.19 in the hyperthermic bird. This pattern was also seen in the breast muscle, kidney and liver. An opposite pattern was seen in the heart, where an increase of $266 \%$ occured in the hyperthermic chickens in comparison to the normothermic group.

A different pattern was seen in the ratio of the enzymes lactic dehydrogenase to aspartate aminotransferase, with decreases in the brain, kidney, liver and lung (tab. 2).

\section{Discussion}

Living cells, as well as whole animals, can adapt to changing conditions by modifying the biological systems to meet the new needs by enhancing or suppressing enzymes which produce or excrete metabolites, creating new equilibriums (6).

High environmental temperature, leading to hyperthermia, leads to a sequence of physiological and metabolic changes resulting from the need to cool the body temperature or compensate metabolic events originating from hyperthermia. In the chicken, as well as other animals, one way of cooling the body is accomplished by panting - using the lungs, for evaporative cooling, with eventual loss of carbon dioxide and development of respiratory alkalosis (7). One way for adapting to the new blood gas levels is by regulating the levels of phosphorylated intermediates such as 2,3 bisphosphoglycerate or inositol-5-phosphate which affect oxygen and carbon dioxide affinity to haemoglobin $(6,7)$.

In the present research, the effect of long term high environmental temperature on enzyme activities in the blood and tissue cells was studied. As seen from the results, there were significantly large changes in the levels of enzymes in all organs studied.

The effects of prolonged heat stress on enzymatic makeup and response could be evaluated from the degree of changes and from ratios of enzymes associated with different metabolic pathways.

The intracellular concentrations of key enzymes in various metabolic pathways, which are depicted in table 1 , give some picture about the degree of involvement of some reactions in relation to the metabolic activities in the tissue. As seen, there are very large quantitative differences in enzyme concentration in the different tissues. By evaluating the effects of long term hyperthermia on organ tissues, it was clear that adaptation to stress conditions took place, as evidenced by enzyme expression.

Changes in intracellular enzyme activities seem to be associated with the new conditions created by the hyperthermia. One such change relates to the increased beating heart rate, which is associated with hyperthermia $(1-4)$. An increase in heart size and weight was also seen. However, in addition to the mass increase, intracellular quantitative changes of enzymes were also seen. Of interest is the dramaticly increased (mean $328 \%$ ) activity of creatine kinase, suggesting the greater demand and involvement of energy related activities. Another aspect related to heart function is the increased activities of both lactic dehydrogenase and alanine aminotransferase, two enzymes having a common substrate - pyruvate, suggesting increased metabolism at the point

Tab. 2 Effect of environmental temperature and long term hyperthermia on enzyme ratios in various tissues

\begin{tabular}{|c|c|c|c|c|c|c|c|}
\hline \multirow[t]{2}{*}{ Enzyme ratios } & \multirow[t]{2}{*}{ Group } & \multicolumn{6}{|c|}{ Organ Tissue } \\
\hline & & Brain & $\begin{array}{l}\text { Breast } \\
\text { muscle }\end{array}$ & $\begin{array}{l}\text { Heart } \\
\text { muscle }\end{array}$ & Kidney & Liver & Lung \\
\hline Lactic dehydrogenase & Control & 0.53 & 1.26 & 2.34 & 7.37 & 67.40 & 1.88 \\
\hline creatine kinase & Hyperthermic & 0.19 & 0.69 & 8.58 & 4.32 & 45.96 & 2.11 \\
\hline Lactic dehydrogenase & Control & 4.89 & 70.00 & 2.99 & 6.10 & 6.07 & 10.49 \\
\hline$\overline{\text { aspartate aminotransferase }}$ & Hyperthermic & 1.08 & 98.26 & 3.34 & 4.04 & 3.82 & 4.29 \\
\hline
\end{tabular}


where the anaerobic glycolytic pathway meets with the aerobic Krebs cycle. The increased activities of these two enzymes suggest that increased production of pyruvate takes place for the production of more adenosine triphosphate. Enzymes such as alkaline phosphatase, not having a critical metabolic role in the heart muscle, did not show any change in activity.

Comparing changes in skeletal and cardiac muscles shows a distinct difference between the two tissues. While in the heart the increase in creatine kinase activity was very high and the increase in lactic dehydrogenase activity was smaller, in the skeletal muscle, the increase in creatine kinase activity was only $18 \%$ of that seen in the heart and no significant change in lactic dehydrogenase activity was seen. This penomenon could be related to the fact that the two tissue types are different, and behave differently to feed back mechanism by lactic acid (6).

The kidney is another organ which is strongly stressed during hyperthermia and the consequent development of respiratory alkalosis. In the body, a compensatory process for respiratory alkalosis involves the kidneys ridding excess basic elements and producing, or keeping, the acidic radicals to neutralize alkalosis and maintain the physiological pH $(17-19)$. As seen, the activities of enzymes involved in the processes of energy transfer (creatine kinase), or energy utilization (alkaline phosphatase) were greatly increased. Similarly, the enzyme $\gamma$-glutamyltransferase, involved in the $\gamma$-glutamyl cycle and probably involved in amino acids metabilism, was significantly increased. Although the exact relation to the stressed condition is not clear, it could be associated with ammonia metabolism in relation to the metabolic compensatory effect due to respiratory alkalosis. Furthermore, the increased load of metabolism is also reflected in the increased activities of energy related processes and the enzyme creatine kinase.

Of interest is the response seen in the brain of chickens exposed to prolonged hyperthermia. The pattern of the changes seen was different from that of the skeletal and cardiac muscle. While lactic dehydrogenase activity was significantly reduced, a very large increase in activity was seen for aspartate aminotransferase. This response reflects metabolic events having different needs and pri- orities. Due to the complexity of this organ and lack of complete basic information, this phenomenon cannot be explained.

The organ least affected was the liver, with small or no changes in enzymatic activities. The reasons for this could be related to the fact that the liver, unlike many other organs in the body, has a very large reserve capacity, which could be easily adapted to new needs.

Evaluation of the changes due to l'ong-term hyperthermia, the individual enzymes reveal some interesting patterns, pointing to a common event. One such observations is the increased activity of the enzyme creatine kinase, which was elevated in all organs except the lungs, pointing to the big demand for energy related processes.

Similarly, a pattern seen in most tissue reveals an increase in the cellular activity of alanine and aspartate aminotransferases. The changes seen were in the more stressed organs, where apparently a greater metabolic activity takes place and requires the involvement of amino and organic acids to supplement these activities.

The degree of stress on the various organs can be seen from the degrees of changes in each organ. It can be seen that heart muscle, kidney and brain were more affected than breast muscle, liver and lungs. The different patterns and different degree of the changes seen, further suggests different metabolic pathways in each organ, reflecting its function and response to prolonged heat stress.

It is interesting that even though the intracellular changes were large, they did not significantly change the enzyme levels in the chicken's serum (15). This suggests that virtually no cellular damage, resulting in leakage of intracellular enzymes into the blood, took place.

The intracellular biochemical changes seen in the hyperthermic chicken were a reflection of the metabolic stress caused by heat. The degree of response of each organ reflected the degree of stress on that organ. The evaluation of intracellular biochemical changes proves to be a sensitive method for the evaluation of the degree of stress caused by hyperthermia and the ability of the body to cope with it by changing the metabolism.

\section{References}

1. Van Kampen $M$. Some aspects of thermoregulation in the white Leghorn fowl. Int J Biometer 1971; 15:244-6.

2. Polonis $\mathrm{A}$. The influence of the thermal factor on some biochemical indices of chicken blood plasma. Pol Arch Veter $1982 ; 28: 49-56$.

3. Kobne HJ, Jones JE. Changes in plasma electrolytes, acid-base balance and other physiological parameters of adult female turkeys under conditions of acute hyperthermia. Poulty Sci 1975; 54:2034-8.

4. Ward MA, Peterson RA. The effect of heat exposure on plasma uric acid, lactate dehydrogenase, chloride, total protein and zinc of the broiler. Poultry Sci 1973; 52:1671-3.

5. Tietz, NW. Fundamentals of clinical chemistry. Philadelphia, London, Toronto: WB Saunders Company. 1970:267-73.

6. Lehninger A. Biochchemistry. 2nd ed. New York: Worth Publishers Inc, 1975.

7. Whittow GC. Regulation of body temperature. In: Sturkie PD, editor. Avian physiology. 4th ed. New York, Heidelberg, Tokyo: Springer Verlag, 1986:221-52. 
8. Bowen SJ, Washburn KW. Genetics of heat tolerance in Japanese quail. Poultry Sci 1984; 63:430-5.

9. Van Handel-Hruska JM, Wegner TN, Nordstrom JO. Avian cardio-vascular responses following high environmental temperature acclimation. Fed Am Soc Exp Biol 1977; 36:524.

10. Bogin E, Weisman Y, Friedman Y. Effect of heat shock on the biochemical composition of chicken blood. Ref Vet 1981; 38:(3) $98-104$

11. Odom TW, Harrison PC, Bottje WG. Effects of thermal induced respiratory alkalosis on blood ionized calcium levels in the domestic hen. Poultry Sci 1985; 65:570-3.

12. Arad Z, Marder J, Eylath U. Serum electrolytes and enzyme responses to heat stress and dehydration in the fowl. Comp Biochem Physiol 1983; 74A:449-53.

13. Arad Z, Marder J. Acid base regulation during thermal panting in the fowl: comparison between breeds. Comp Biochem Physiol 1983; 74A:125-30.

14. Darre MJ, Odom TW, Harrison PC, Staten FE. Time course of change in respiratory rate, blood $\mathrm{pH}$ and blood $\mathrm{pCO}_{2}$ of SCWL hens during heat stress. Poultry Sci 1980; 59:1598-605.

15. Pech-Waffenschmidt V, Bogin E, Avidar Y, Horst P. Metabolic and biochemical changes during heat stress in relation to the feathering degree of the domestic hen. Avian Pathology 1995; $24: 33-44$.

16. Bogin E, Avidar $Y$, Pech-Waffenschmidt V, Doron $Y$, Israeli Bat-Ami, Kevkhayev, Erna Horst P. The relationship between heat stress, survivability and blood composition of the domestic hen. Eur J Clin Chem Clin Biochem 1996; 34:463-9.

17. Kaneko JJ. Clinical biochemistry of domestic animals. London, Toronto, San Francisco: Acad Press 1989.

18. White A, Handler P, Smith EL, Hill RL, Lehman IR. Principles of biochemistry. 6th ed. New York: McGraw-Hill Book Co, 1978.

19. Bogin E. Handbook of animal clinical chemistry. New York: Kodak Publ. USA, 1992.

20. Bogin A, Avidar Y, Merom M. Biochemical changes in liver and blood during liver fattening in rats. $\mathrm{J}$ Clin Chem Clin Biochem $1986 ; 24: 621-6$.
21. Tietz NW, Burtis CA, Duncan P, Erwin K, Petitclerc CJ, Rinker D, et al. Measurement of alkaline phosphatase activity in human serum, study group on alkaline phosphatase. Clin Chem 1983; 29:751-61.

22. Bergmeyer HU, Hørder M, Rej R. Approved recommendation (1985) on IFCC methods for the measurement of catalytic concentration of enzymes IFCC method for alanine aminotransferase. J Clin Chem Clin Biochem 1986; 24:481-95.

23. Bergmeyer HU, Hørder M, Rej R. Approved recommendation (1985) on IFCC methods for the measurement of catalytic concentration of enzymes. IFCC method for aspartate aminotransferase. J Clin Chem Clin Biochem 1986; 24:497-10.

24. Hørder M, Magid E, Pitkanen E, Harkonen M, Strømme JH, Theodorsen KV, et al. Method for determination of creatine kinase in blood modified by inclusion of EDTA. Scand J Clin Lab Invest 1979; 39:1-5.

25. Keiding R, Herder M, Gerhardt W, Pitkanen E, Tenhunen R, Strømme $\mathrm{JH}$, et al. Recommended methods for determination of four enzymes in blood. Scand J Clin Lab Invest 1974; 33:291-306.

26. Szasz G. Reaction rate method for gamma-glutamyltransferase activity in serum. Clin Chem 1976; 22:2052-5.

27. Lowry $\mathrm{OH}$, Rosebrough NJ, Farr AL, Randall RS. Protein measurement with the Folin phenol reagent. J Biol Chem 1951; 193:265-75.

28. SAS Institute Inc. SAS user's guide: Statistics, Carry, NC, NY. SAS Institute Inc. 1985.

Received February 21/June 7. 1996

Corresponding author: Prof. Dr. Eitan Bogin, Department of Biochemistry, Kimron Veterinary Institute, Tel-Aviv University, P. O. Box 12, Beit-Dagan, 50250 Israel 
